\title{
A Review of Research on the Effects of Music upon Second Language Acquisition
}

\author{
Nur Azmina Zafirah Binti Mohammad Amin, Or-Kan Soh* \\ School of Language Studies \& Linguistics, Faculty of Social Sciences \& Humanities, Universiti Kebangsaan Malaysia, Malaysia
}

Received November 28, 2019; Revised December 20, 2019; Accepted December 25, 2019

Copyright $\subseteq 2020$ by authors, all rights reserved. Authors agree that this article remains permanently open access under the terms of the Creative Commons Attribution License 4.0 International License

\begin{abstract}
Music and songs have been long used as an attractive approach to enhance the skills in second language learning. While the majority of the existing research has been focused mainly on the value of using music to acquire language skills, researchers have recently started to delve into its prospective within the educating development. The qualitative synthesis consists of qualitative and quantitative research targeted to address the gaps observed in the literature regarding the integration of music into pedagogical strategies. There were six main findings materialized: (a) a fluctuation trend shown in using music in the pedagogical strategies; (b) the theoretical and conceptual perspectives of using music to enhance the skills of the second language; (c) the variation of perceptions, attitudes and usage patterns; (d) the effects on integrating music in the pedagogical strategies; (e) the identified challenges were listed out; and (f) proven affordances support in using music to second language learners. The findings were interpreted to determine the implications on music developments upon second language learners in the teaching area including the direction progress for the integration and study.
\end{abstract}

Keywords Music as a Learning Tool, Second Language Acquisition, English Language Learners

\section{Introduction}

Songs have been a part of our lives for as long as we can remember. Guglielmino (1986) mentioned adults sing at religious services, bars, in the shower and listen to songs on the car radio. It has become essential to our lives. Music is a great language package that bundles culture, vocabulary, listening, grammar and a host of other language components in just a few rhymes. Singing songs not only helps many students remember important information, but it also makes the classroom learning livelier (Campbell \& Dickinson, 1996). Students who possess good listening comprehension skills can participate more effectively in communicative situations and class (Brown, 2001). According to Peacock (1997), many writers share the same opinion that learners are more motivated and stimulated in the foreign language classroom when authentic materials are used than artificial non-authentic materials. Orlova (2003), states that there is a great connection between students' motivation and authentic materials. It is a very good way to expose the targeted language to the learners as well as facilitating their learning. Encouraging language and communication skills in children under five is an essential part of child development and music-related play is an excellent way to accomplish it (Lee, 2004). According to Medina (1993), a wide variety of useful vocabulary items can be acquired through popular songs. Using students' favorite songs to teach vocabulary creates endless opportunities for revision which is fundamental for storing the information in long term memory (Murphey, 1992). It can be said that almost everyone loves music and songs which can be used to not only lift their mood but also as a tool to aid their language. For many people from all around the world, the first exposure to English is through popular song lyrics. Moreover, the use of music in language classes puts students at ease, makes them more attentive and can increase their desire to learn a language (Mishan, 2005). Music and songs add meaning to people's lives. Music and lyrics allow people to express their feelings, ideas, and thoughts. Singing and listening to music has the power to excite, move, soothe learners and make them feel relaxed in the language classroom (Abbott, 2002). Songs aid memory and enhance language learning also, it is easy for learners to remember new words and phrases through songs. Many lyrics are known to be repetitive moreover, many lyrics contain formulaic chunks which are helpful for learners in future conversation (Meiling, 2007). According to Lieberstein (1996), teachers can have different ways to use music in the classroom. They can 
use both background music and lyrics as the basis of a lesson, but they should know how they can effectively use music in their English learning classrooms.

The ambiguity of the previous research results suggests the need to delve further into how music has been used to enhance the skills in second language acquisition. Thus, this review aims to improve the understanding of how the effects of music and songs that are being used in the pedagogical strategies can create development on second language learners.

\section{Research Questions}

There were a lot of advantages, limitations, effectiveness, challenges, etc. on the past researched reviewed of music upon second language acquisition. Within this context the research questions addressed by this study are:

1. What are the trends in using music in the pedagogical strategies and the theoretical perspectives of using music to enhance the skills of second language?

2. What are the variation of attitudes and the effects on integrating music in the pedagogical strategies among second language learners?

3. What are the challenges and proven affordances support in using music to second language learners?

\section{Research Method}

According to Burns (1999), the major focus of action research is on concrete and practical issues of immediate concern to particular social groups or communities. Given the methodological diversity of music upon second language acquisition, this review is a qualitative synthesis of quantitative and qualitative research. A qualitative synthesis can be defined as, "systematic efforts of synthesizing qualitative research" (Suri \& Clarke, 2009, p. 401). A literature review and analysis were conducted covering journal publications from 2001 to 2016 .

\subsection{Literature Search Strategy}

Relevant publications were chosen from Google scholar, ERIC, Scopus, and Elsevier. Then, the following search terms were applied in different combinations: music, second language acquisition, English language learners, songs, language skills development, YouTube and radio. Some examples of combinations of these terms include "Music in second language acquisition", "Music and language learners", and "Music on language skills". To ensure the reliability of the publications, the guidelines from Webster and Watson (2002) were followed to conduct the literature reviews, where the author suggested starting with contributions published in leading journals when identifying relevant literature. Subsequently, throughout the chosen search tools, 45 articles were identified. To gain further reliability, search results were refined by carefully examining all the retrieved articles' titles, abstracts, and keywords, where the terms are specifically searched on "music", "second language acquisition", and "English language learners". The searched articles using the tools mentioned were about 95\% relevant to the initial search terms (e.g., about learning music or music in the classroom), however, they were not about learning language through music. Thus, the articles were excluded. Subsequently, 20 articles were identified related to the main searched.

The identified 20 articles which are closest related to the search terms were examined and coded with notations in an analytic research synthesis table including the meta-categories of the study of the effects of music upon second language acquisition, the samples, purpose of the study, time frame, sample size, and the final findings. Those notations were included to evaluate the comparisons among the studies (see table 1). 
Table 1. An analysis of studies on the effects of music upon second language acquisition $(n=20)$

\begin{tabular}{|c|c|c|c|c|}
\hline Study & Subjects & Study Purpose & Sample Size & Country \\
\hline $\begin{array}{l}\text { Fisher, D. (2001). Early Language } \\
\text { Learning } \\
\text { With and Without Music. } \\
\text { Reading Horizons: } \\
\text { A Journal of Literacy and Language } \\
\text { Arts, } 42 \text { (1). }\end{array}$ & $\begin{array}{ll}\text { The use of } \\
\text { music } & \text { in } \\
\text { classroom } & \end{array}$ & $\begin{array}{l}\text { to determine if the use of music } \\
\text { in primary grade classrooms } \\
\text { resulted in increased literacy } \\
\text { performance of students in } \\
\text { bilingual programs. }\end{array}$ & $\begin{array}{lr}80 \quad \text { students } & \text { (from } \\
\text { kindergartens } & \text { until } \\
\text { primary) who spoke } \\
\text { Spanish }\end{array}$ & Spain \\
\hline $\begin{array}{l}\text { Morales Neisa, C. (2008). Using rock } \\
\text { music as a teaching-learning tool. } \\
\text { Profile Issues in Teachers Professional } \\
\text { Development, (9), 163-180. }\end{array}$ & $\begin{array}{l}\text { Rock music } \\
\text { and learning }\end{array}$ & $\begin{array}{l}\text { to explore the teaching/learning } \\
\text { potential rock songs have in } \\
\text { English language lessons with } \\
\text { two adult private students }\end{array}$ & $\begin{array}{l}\text { Three private lessons } \\
\text { with two students }\end{array}$ & Colombia \\
\hline $\begin{array}{l}\text { Beasley, R. E., \& Chuang, Y. (2008). } \\
\text { Web-Based Music Study: The Effects } \\
\text { of Listening Repetition, Song } \\
\text { Likeability, and Song Understandability } \\
\text { on EFL Learning Perceptions and } \\
\text { Outcomes. TESL-EJ, 12(2), n2. }\end{array}$ & $\begin{array}{l}\text { Web based } \\
\text { music in the } \\
\text { EFL } \\
\text { classroom }\end{array}$ & $\begin{array}{l}\text { To study if listening to repetition, } \\
\text { song likeability, and/or song } \\
\text { understandability influence the } \\
\text { learning environment } \\
\text { perceptions, learning perceptions, } \\
\text { and/or learning outcomes in } \\
\text { Taiwanese EFL learners that are } \\
\text { engaged in web-based music } \\
\text { study. }\end{array}$ & $\begin{array}{l}196 \text { higher institutions } \\
\text { Taiwanese students. }\end{array}$ & Taiwan \\
\hline $\begin{array}{l}\text { Lee, L. Y. L. (2009). An Empirical } \\
\text { Study on Teaching Urban Young } \\
\text { Children Music and English by } \\
\text { Contrastive Elements of Music and } \\
\text { Songs. Online Submission, 6(3), 28-39 }\end{array}$ & $\begin{array}{l}\text { Composing } \\
\text { creative music } \\
\text { and songs with } \\
\text { contrast } \\
\text { elements. }\end{array}$ & $\begin{array}{l}\text { To teach urban young children } \\
\text { music concepts and English by } \\
\text { composing creative music and } \\
\text { songs with contrast elements. }\end{array}$ & $\begin{array}{l}\text { Seven urban young } \\
\text { children aged from three } \\
\text { to four in a Taiwan } \\
\text { kindergarten }\end{array}$ & Taiwan \\
\hline $\begin{array}{l}\text { Arevalo, E. A. R. (2010). The use of } \\
\text { songs as a tool to work on listening and } \\
\text { culture in EFL classes. Cuadernos de } \\
\text { lingüística hispánica, (15), 121-138. }\end{array}$ & $\begin{array}{l}\text { Music as a } \\
\text { listening tool. }\end{array}$ & $\begin{array}{l}\text { To examines the listening } \\
\text { performance of students } \\
\text { throughout the development of } \\
\text { six workshops based on the } \\
\text { songs: Englishman in New York, } \\
\text { Imagine, Mercedes Benz, Cats in } \\
\text { the cradle, Zombie, and Where is } \\
\text { the love? }\end{array}$ & $\begin{array}{l}\text { This project was carried } \\
\text { out at a university } \\
\text { foundation in Tunja, } \\
\text { Boyacá. }\end{array}$ & Colv \\
\hline $\begin{array}{l}\text { Pérez Niño, D. F. (2010). The role of } \\
\text { music in young learners' oral production } \\
\text { in English. Profile Issues in } \\
\text { TeachersProfessional Development, } \\
12(1), 141-157 .\end{array}$ & $\begin{array}{l}\text { Oral } \\
\text { production by } \\
\text { making and } \\
\text { listening to } \\
\text { music }\end{array}$ & $\begin{array}{l}\text { To study how young learners who } \\
\text { study English can develop their } \\
\text { oral production by making and } \\
\text { listening to music }\end{array}$ & $\begin{array}{l}\text { students from } 10 \text { to } 15 \\
\text { years old in Universidad } \\
\text { Nacional de Colombia, in } \\
\text { Bogotá }\end{array}$ & Columbia \\
\hline $\begin{array}{l}\text { Abidin, Z., Jafre, M., } \\
\text { Pour-Mohammadi, M., Singh, B., Kaur, } \\
\text { K., Azman, R., \& Souriyavongsa, T. } \\
(2011) \text {. The Effectiveness of Using } \\
\text { Songs in YouTube to Improve } \\
\text { Vocabulary Competence among Upper } \\
\text { Secondary School Studies. Theory \& } \\
\text { Practice in Language Studies, 1(11). }\end{array}$ & $\begin{array}{ll}\text { The use of } \\
\text { songs } & \text { in } \\
\text { YouTube } & \end{array}$ & $\begin{array}{l}\text { To investigate whether learners } \\
\text { exposed to songs using YouTube } \\
\text { would experience a change in } \\
\text { vocabulary competence compared } \\
\text { to those exposed to the traditional } \\
\text { teacher-fronted approach }\end{array}$ & $\begin{array}{l}68 \text { Form Four students } \\
\text { were selected from a } \\
\text { government-run } \\
\text { secondary school located } \\
\text { in Kedah, Malaysia. }\end{array}$ & Malaysia \\
\hline $\begin{array}{l}\text { Setia, R., Rahim, R. A., Nair, G. K. S., } \\
\text { Husin, N., Sabapathy, E., Mohamad, } \\
\text { R., ... \& Kassim, R. M. (2012). English } \\
\text { songs as means of aiding students' } \\
\text { proficiency development. Asian Social } \\
\text { Science, } 8(7), 270 \text {. }\end{array}$ & $\begin{array}{l}\text { Use of songs in } \\
\text { teaching } \\
\text { English among } \\
\text { primary } \\
\text { students }\end{array}$ & $\begin{array}{l}\text { to determine the effectiveness of } \\
\text { using songs in teaching English } \\
\text { language to primary school } \\
\text { students. }\end{array}$ & $\begin{array}{l}61 \text { students from a } \\
\text { private primary Islamic } \\
\text { school in Dungun in year } \\
4 \text {, year 5, year } 6 \text {. }\end{array}$ & Malaysia \\
\hline $\begin{array}{l}\text { Zarei, A. A., \& Salimi, A. (2012). The } \\
\text { comparative effects of song, picture and } \\
\text { the keyword method on L } 2 \text { vocabulary } \\
\text { recognition and production. Applied } \\
\text { Research in English, 1(1), 43-56 }\end{array}$ & $\begin{array}{l}\text { Use of song, } \\
\text { picture and } \\
\text { keyword } \\
\text { method }\end{array}$ & $\begin{array}{l}\text { To study the effects of three } \\
\text { methods of vocabulary } \\
\text { presentation, i.e., picture, song, } \\
\text { and the keyword method on } \\
\text { Iranian EFL learners' vocabulary } \\
\text { recognition and production. }\end{array}$ & $\begin{array}{l}102 \text { Iranian } \\
\text { lower-intermediate EFL } \\
\text { learners in Zaban Sara } \\
\text { English language } \\
\text { institute in Kermanshah. }\end{array}$ & Iran \\
\hline
\end{tabular}




\begin{tabular}{|c|c|c|c|c|}
\hline $\begin{array}{l}\text { Köksal, O., Yağışan, N., \& Çekiç, A. } \\
\text { (2013). The effects of music on } \\
\text { achievement, attitude and retention in } \\
\text { primary school English lessons. } \\
\text { Procedia-Social and Behavioral Sciences, } \\
93,1897-1900 \text {. }\end{array}$ & $\begin{array}{l}\text { Music on } \\
\text { vocabulary }\end{array}$ & $\begin{array}{l}\text { To determine the effect of teaching } \\
\text { English vocabulary to } 5 \text { th graders } \\
\text { through music on their achievement } \\
\text { in vocabulary, attitudes towards } \\
\text { English course and retention of new } \\
\text { words. }\end{array}$ & $\begin{array}{l}\text { Primary school 5th } \\
\text { grader }\end{array}$ & Turkey \\
\hline $\begin{array}{l}\text { Shabani, M. B., \& Torkeh, M. (2014). The } \\
\text { relationship between musical intelligence } \\
\text { and foreign language learning: The case } \\
\text { of Iranian learners of English. } \\
\text { International Journal of Applied } \\
\text { Linguistics and English Literature, 3(3), } \\
\text { 26-32. }\end{array}$ & $\begin{array}{l}\text { Musical } \\
\text { intelligence } \\
\text { and language } \\
\text { proficiency }\end{array}$ & $\begin{array}{l}\text { To examined the relationship } \\
\text { between musical intelligence and } \\
\text { foreign language learning }\end{array}$ & $\begin{array}{lr}140 \text { Persian } & \text { native } \\
\text { speakers } & (100 \\
\text { females, } 40 & \text { males }) \\
\text { ages } 15 \text { to } 18 & \end{array}$ & Iran \\
\hline $\begin{array}{l}\text { Moradi, F., \& Shahrokhi, M. (2014). The } \\
\text { Effect of Listening to Music on Iranian } \\
\text { Children's Segmental and Suprasegmental } \\
\text { Pronunciation. English Language } \\
\text { Teaching, 7(6), 128-142. }\end{array}$ & $\begin{array}{l}\text { Music in } \\
\text { segmental and } \\
\text { suprasegmental } \\
\text { pronunciation }\end{array}$ & $\begin{array}{l}\text { To find out whether children } \\
\text { learning English by music can } \\
\text { improve their ability in segmental } \\
\text { and suprasegmental pronunciation } \\
\text { or not. }\end{array}$ & $\begin{array}{l}30 \text { female elementary } \\
\text { students with the age } \\
\text { between } 9 \text { to } 12 \text { years } \\
\text { old were chosen }\end{array}$ & Iran \\
\hline $\begin{array}{l}\text { Yousefi, A., Yekta, R. R., \& } \\
\text { Farahmandian, H. (2014). The Effect of } \\
\text { Modern Lyrical Music on Second } \\
\text { Language Vocabulary Acquisition. } \\
\text { Mediterranean Journal of Social Sciences, } \\
5(23), 2583 \text {. }\end{array}$ & $\begin{array}{l}\text { Modern lyrical } \\
\text { music }\end{array}$ & $\begin{array}{l}\text { To investigate the effect of music on } \\
\text { second language vocabulary } \\
\text { acquisition and to investigate the } \\
\text { effect of music on long term } \\
\text { retention of vocabulary }\end{array}$ & $\begin{array}{l}\text { sixty girl students of a } \\
\text { junior high school }\end{array}$ & Iran \\
\hline $\begin{array}{l}\text { Abdolmanafi-Rokni, S. J., \& Ataee, A. J. } \\
\text { (2014). The effect of background music } \\
\text { on vocabulary recall and retention of } \\
\text { children learning English as a foreign } \\
\text { language. International Journal of Basic } \\
\text { Sciences \& Applied Research, 3(8), } \\
\text { 491-495. }\end{array}$ & $\begin{array}{l}\text { Background } \\
\text { music in the } \\
\text { classroom }\end{array}$ & $\begin{array}{l}\text { To examine whether addition of } \\
\text { background music in the classroom } \\
\text { would have any effect on Iranian } \\
\text { children' vocabulary recall and } \\
\text { retention. }\end{array}$ & $\begin{array}{l}34 \text { elementary level } \\
\text { learners from two } \\
\text { classes studying in an } \\
\text { institute in Iran age } \\
\text { from } 7 \text { to } 11 .\end{array}$ & Iran \\
\hline $\begin{array}{l}\text { Moradi, M., \& Zamanian, M. (2014). On } \\
\text { effect of soft music on learning English } \\
\text { language vocabulary. Theory and Practice } \\
\text { in Language Studies, } 4(2), 341 \text {. }\end{array}$ & $\begin{array}{l}\text { Soft music on } \\
\text { learning } \\
\text { English }\end{array}$ & $\begin{array}{l}\text { To search whether the use of soft } \\
\text { music during studies improves } \\
\text { student's learning of English } \\
\text { language words, especially students } \\
\text { learning and memorizing words in } \\
\text { real-life situation }\end{array}$ & $\begin{array}{l}70 \text { male intermediate } \\
\text { EFL learners of } \\
16-20 \text {, studying at } \\
\text { Talash Language } \\
\text { Institute (TLI), } \\
\text { Kazeroun branch }\end{array}$ & Iran \\
\hline $\begin{array}{l}\text { Tse, A. Y. H. (2015). Malaysian teachers' } \\
\text { perspectives on using songs in English } \\
\text { language teaching. International Journal } \\
\text { of Social Science and Humanity, 5(1), } 87 \text {. }\end{array}$ & $\begin{array}{l}\text { Malaysian ESL } \\
\text { teachers } \\
\text { perspectives on } \\
\text { using songs }\end{array}$ & $\begin{array}{l}\text { To survey the perspectives of } \\
\text { English as a Second Language } \\
\text { (ESL) teachers in Malaysian state } \\
\text { primary schools on using songs to } \\
\text { teach English to young learners } \\
\text { (YLs) }\end{array}$ & $\begin{array}{l}60 \text { Malaysian ESL } \\
\text { primary teachers from } \\
\text { ten primary schools in } \\
\text { Kuantan and } \\
\text { Gambang }\end{array}$ & Malaysia \\
\hline $\begin{array}{l}\text { Alipour, M., Gorjian, B., \& Zafari, I. } \\
\text { (2012). The effects of songs on EFL } \\
\text { learners' vocabulary recall and retention: } \\
\text { The case of gender. Advances in digital } \\
\text { multimedia, 1(3), 140-143. }\end{array}$ & $\begin{array}{l}\text { Songs } \\
\text { gender }\end{array}$ & $\begin{array}{l}\text { To investigate the effects of songs } \\
\text { on vocabulary learning of } \\
\text { upper-level language learners based } \\
\text { on their gender. }\end{array}$ & $\begin{array}{l}105 \text { male and female } \\
\text { students attending } \\
\text { English in Ahvaz, } \\
\text { Iran } 60 \text { males and } \\
\text { females aged from } 20 \\
\text { to } 32,\end{array}$ & Iran \\
\hline $\begin{array}{l}\text { Augustine, C. (2015). How the use of } \\
\text { music and movement impacts the learning } \\
\text { of reading skills by preschoolers. } \\
\text { Malaysian Journal of Music, 4(2), 74-90. }\end{array}$ & $\begin{array}{l}\text { Music and } \\
\text { movement on } \\
\text { reading skills }\end{array}$ & $\begin{array}{l}\text { To assess the effect of music and } \\
\text { movement on the reading skills of } \\
40 \text { five-year-old pre-schoolers at a } \\
\text { university preschool. }\end{array}$ & $\begin{array}{l}\text { Forty preschool } \\
\text { children which are } \\
\text { five-year-old }\end{array}$ & Malaysia \\
\hline $\begin{array}{l}\text { Rezaei, M., \& Ahour, T. (2015). The } \\
\text { Effect of Listening to English Songs on } \\
\text { Iranian EFL Pre-intermediate Learners' } \\
\text { Listening Comprehension. Journal of } \\
\text { English Language Pedagogy and Practice, } \\
8(16), 159-176 \text {. }\end{array}$ & $\begin{array}{l}\text { Listening to } \\
\text { English songs }\end{array}$ & $\begin{array}{l}\text { To find out whether listening to } \\
\text { English songs can improve } \\
\text { pre-intermediate EFL learners' } \\
\text { listening comprehension }\end{array}$ & $\begin{array}{l}40 \text { male and female } \\
\text { aged } 18-28 \text { English } \\
\text { learners from two } \\
\text { classes in an Institute } \\
\text { in Marand, Iran. }\end{array}$ & Iran \\
\hline $\begin{array}{l}\text { Iman, S. (2016). The effectiveness of } \\
\text { using children's songs in developing } \\
\text { elementary graders' English vocabulary } \\
\text { and pronunciation in Palestine. }\end{array}$ & $\begin{array}{l}\text { Children's } \\
\text { songs }\end{array}$ & $\begin{array}{l}\text { Investigating the effect of using } \\
\text { children's songs in developing the } \\
\text { elementary graders' vocabulary and } \\
\text { pronunciation }\end{array}$ & $\begin{array}{l}123 \text { EFL students of } \\
\text { the fourth grade; } 72 \\
\text { females and } 51 \text { males. }\end{array}$ & Palestine \\
\hline
\end{tabular}




\section{Findings}

Numerous main findings emerged as a result of the research synthesis selected upon 20 articles on the effects of using music upon second language acquisition, outlined below in terms of the trends, theoretical perspectives, perceptions, attitudes, and usage patterns, benefits, challenges, and teacher education contexts.

\subsection{The Trends on the Effects of Using Music upon Second Language Acquisition Literature}

The articles that were examined are bound within the period, between 2001 and 2016. As illustrated in Figure 1, most researched articles were discovered in $2014(\mathrm{n}=5)$. The consistency of using music in the pedagogical strategies has made researchers showed interest in broadening their findings. As shown in Table 1, almost 50\% of the research on using music in second language acquisition was conducted in $\operatorname{Iran}(\mathrm{n}=8)$ followed by Malaysia $(n=4)$ and Colombia $(n=3)$. It is especially noteworthy that other more countries contributed to the mobile learning research in teacher education in recent years, such as Taiwan, Spain, Turkey, and Palestine.

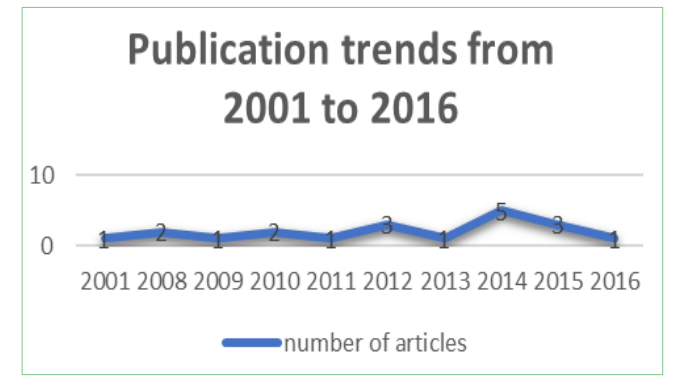

Figure 1. Publication trends from 2001 to 2016

The studies that were examined in this review used several methodologies, with a majority used mixed method From the 20 studies, five were conducted within elementary students, two within kindergarteners, four within University students, five within secondary students, one on teacher's perspective, and three on others such as gender $(\mathrm{n}=1)$, private lesson $(\mathrm{n}=1)$, various ages $(\mathrm{n}=1)$.

\section{Subject Domain}

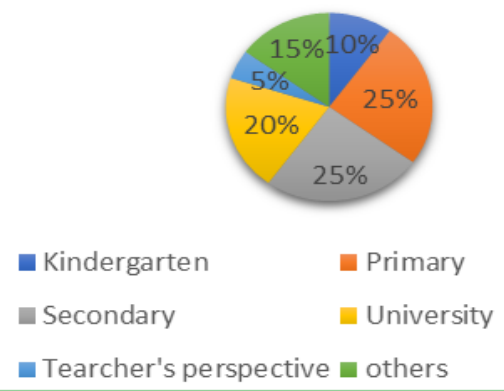

Figure 2. Distribution of studies by subject domain
The articles' research mainly was classified according to three types: (1) Quantitative research, (2) Qualitative research or (3) Qualitative research and quantitative data. majority of the studies were identified as qualitative research $(n=13)$ which focuses on applying music in the pedagogical strategies, while other study was identified as quantitative research $(n=4)$ and using both $(n=3)$ that mainly focusing on surveying participants' usage, perceptions, or attitudes on the use of music in learning the second language. Data sources included questionnaires, interviews, blogs, recordings, observations, journals, usage data, and audio and video transcripts. Music as a tool used to improve listening was the most common pedagogical strategy. The use of music to improve vocabulary or oral production was the most common research has been done $(\mathrm{n}=9)$, followed by using music for learning $(\mathrm{n}=6)$, listening $(n=3)$, reading $(n=1)$ and others such as perceptions towards music $(n=1)$. The studies showed that the implementation of using music as a pedagogical strategy showed a large number that illustrated how language educators' interest in applying music to enhance language learning skills. The continuously risen genres of music have made music as one of the crucial elements for educators to use and it is likely to be used for a long period.

\subsection{Theoretical and Conceptual Perspectives}

The analysis revealed scant reports of theoretical perspectives integrated into using music upon second language acquisition. Among 20 studies, only five are identified using the theoretical framework to design or implement research. To create an interesting language learning environment, Morales (2008) used rock music in English teaching-learning and identified three features on how to use rock music as a learning tool upon second language acquisition. Fornatale (1987) says that two of rock's primary functions have always been to annoy adults and to take a poke at the status quo (p. 3). This explains to some extent the ideological inspiration behind the music itself: to show society those aspects of reality that are too harsh to be shown amiably, though music has been revolutionary in its use of instruments as well. Morales (2008) emphasized how the use of songs in class may be useful if it is done in a way in which the song is treated as something deeper than the entertainment of three to four minutes. Three features were considered important: preliminary consideration, the use of music in listening practices and songs as authentic material. Morales (2008) also states that the use of songs as a teaching material requires previous preparation and careful selection of those songs that want to include in the classes. She added that it does not mean that just a few songs can be useful for teaching; instead, a great variety of music is available for this purpose, though it must remain careful with the selection. Lopera (2003) considers that the inclusion of social contexts, the interaction with students' moods, and the possibility of accessing authentic texts in English are 
important reasons for the inclusion of songs into teaching contexts. Dubin \& Olshtain (1977) consider that the inclusion of music in English lessons is effective because "music is a pleasurable outlet...is a good way for students to relax and feel more at ease in using the new language" (p. 198). Coromina (1993) says rock songs "provide a break from the textbook and workbook routine" (p. 27). Eken (1996) says: "These activities provide a relaxed, friendly and cooperative classroom atmosphere" (p. 47). Also, Morales (2008) added that listening is regarded as one of the most difficult aspects in the mastery of the language, and the material used for this purpose in traditional teaching is not always the most effective, nor the most interesting. Other than that, Augustine (2015) comes up with a theory to promote development language skills to children which were based on sociocultural theory and the Zone of Proximal Development (ZPD) developed by a Russian lawyer, Lev Vygotsky (1896-1934). Vygotsky believed that how children think, and their actions are accomplished through their interactions with adults and older children. Four basic principles are underlying the Vygotskian framework: (a) children construct their knowledge of the world; (b) development occurs within a social context; (c) learning can lead to development; and (d) language is important for cognitive development (Greata, 2006; Smidt, 2009). Furthermore, Beasley \& Chuang (2008) support their study based on three main elements: listening, songs as authentic material and the link between songs and culture. Beasley \& Chuang (2008) stated that listening is so challenging thus, teachers need to think carefully about making the activities successful and the content interesting and motivating activities must be produced when listening such as using English songs. Thus, the students will be stimulated and not be frightened or worried when they are practicing listening, practicing the rhythm, stress and intonation patterns of the English language and teaching vocabulary and grammar. Beasley $\&$ Chuang (2008) continue that music can develop listening comprehension, writing skills, and speaking.

The literature reviewed investigated that some of the frameworks lack new approaches for the use of music in the pedagogical strategies upon second language acquisition. Music can enhance learning skills and is more effective than the usual teaching method. However, the lack of framework in the literature reviewed made it hard for language educators to use as a guide in the pedagogical strategies. The literature needs to establish theoretical models that can be used as a guide for language educators in using music among second language learners. The models need to present effective strategies so that the educators can be equipped with methods for integrating music as a pedagogical strategy.

\subsection{Varied Attitudes and Usage Patterns}

The survey studies that were conducted with kindergarten students' results outcomes regarding perceptions, attitudes, and usage about the effects of music upon second language acquisition. The outcomes depend on the variables in the use of music upon educating second language learners such as the availability and accessibility of technologies, resources, country infrastructure, and motivation of the children and educators. Based on Lee (2009) research, it shows that by using contrastive music pieces is a good way for teaching very young urban children to understand music concepts and she added that by creating simple target objective songs with contrast elements is a good way for them to learn simple foreign language concepts. Lee (2009) continued, music with contrastive elements could motivate urban young children to do movement spontaneously and learn spoken language simultaneously. However, a study by Augustine (2015) shows that music and movement activities impacted pre-schoolers in their overall reading skills, print knowledge, and definitional vocabulary after the intervention, but did not impact on their phonological awareness skills.

A study conducted on primary students has shown various results in Kedah, Malaysia by Abidin et al. (2011) as the results outcomes by using songs on YouTube resulted that the experimental group had far more significant improvement in their vocabulary competence as compared to the control group. They were given more opportunities to work independently in the target language as opposed to the control group. The control group, on the other hand, went through the traditional teacher-fronted approach and was given a limited opportunity for interaction. With this, the use of YouTube can improve vocabulary competence among secondary school students and is indeed an interesting and effective method. Another study on primary students by Setia et al. (2012) was conducted in Dungun, Terengganu resulted that majority of the subjects agreed that using songs to learn English is an effective tool in acquiring vocabulary and improving pronunciation. They added that If the students are exposed to songs which they enjoy, more meaningful learning is likely to occur since they may also find and listen to the music outside of the classroom. Also, the repetitive style of songs then helps to promote the automatization of colloquial language. Continue to another study by Köksal, Yağışan, \& Çekiç (2013) shows how music affects primary students in the 5 th grader. The result of the study indicates that teaching new vocabulary through music has significantly increased achievement in English vocabulary learning, attitudes towards English course and retention of a new vocabulary of the students in the experimental group compared to the control group. Besides, research by Moradi, \& Shahrokhi (2014) on Iranian students resulted that by using music the experimental group outperformed the control group in segmental articulation, including the pronunciation of vowels, consonants, diphthongs, and triphthongs. Subsequently, a study by Abdolmanafi \& Ataee (2014) among 17 students in primary schools 
resulted that by listening to background music had positive effects on the learners' paying attention to the teacher. The results showed that listening to background music had a significantly positive effect on the learners' vocabulary development compared to the learners that were not exposed to background music.

Studies among secondary school students that use music to learn the second language showed various results. Pérez (2010) from the findings he stated that by using music in the classroom the children enjoyed doing listening activities like filling in the blanks and discussing the whole meaning of the songs as well as the unknown vocabulary they found. He added, musical instruments were useful to explain to students some important concepts related to music such as the specific features about the appearance and sound of each one of these instruments. Other than that, research by Shabani \& Torkeh (2014) results findings that inclusion of music program in the learning of foreign language classroom can have benefits such as providing smoothing condition, stimulating creative process, increasing students' motivation for learning, activating linguistic information stored in the memory, helping students to concentrate and connect with their inner self, and improving writing, reading, listening, and speaking skills in language learning process. Yousefi et al (2014) stated from their findings the music group outperformed the no-music group both in short- and long-term retention. The results show that music has a positive effect on vocabulary acquisition. Evidence shows that music benefits rote memorization when various types of verbal information (e.g., multiplication tables, spelling lists) have been presented with music, memorization has been enhanced. Findings from the study of Rezaei \& Ahour (2015) resulted that although there was no significant difference in the listening comprehension of the experimental and control groups in the pretest, there was a significant difference between both groups' mean scores at the end of the study in the posttest, implying a better performance of the experimental group in which the songs were used to boost their listening comprehension.

For higher institutions students there are several studies conducted and the outcomes were various. Beasley \& Chuang (2008) a study on Web-Based Music Study among Taiwanese students resulted that songs are the most suitable type of authentic material to develop listening comprehension. This is because students feel motivated when working with this kind of material; furthermore, learners' ages and social contexts fit with the kind of music we select to work in class. Continuously, research in the institute of Kermanshah among Iranian students resulted that indicate that the keyword method had a significant effect on both vocabulary recognition and production, compared with the song. Also, the students instructed through picture had the best performance in both vocabulary recognition and production (Zarei \& Salimi, 2012). Subsequently, research by Arevalo (2010) stated that through songs students become familiar with the pronunciation of native speakers, and they also provide topics for discussion. He added understanding the language and culture students are learning through songs is much more attractive for them.

Based on this review of the scant report, the validity and reliability issues in the survey studies are identified and there were only three studies recognized to describe using a pilot test. With this limited information on the issues, it makes it difficult to compare all the questionnaires from the studies collected. Thus, the research on this is would be beneficial to discuss the methods use and are more detailed about the context used to investigate the use of music upon second language acquisition.

\subsection{The Effects on Integrating Music in the Pedagogical Strategies among Second Language Learners}

Based on past studies and the literature on using music upon second language acquisition, the majority of the studies resulted that music is one of the most beneficial learning tools to enhance language learning. There are various of encouraging factors for integration of music into kindergarteners to learn the language, such as by composing creative music and songs with contrast elements also motivates young children to do movement spontaneously and learn the spoken language simultaneously (Lee, 2009). Using music and movement impacts the learning of reading skills (Augustine, 2015).

Other studies that researched the use of music in the pedagogical strategy's majority reported positive impacts on the outcomes studied. Music is acknowledged to be essentials in helping language educators mostly to develop language skills and enhance it (Fisher, 2001). Real Texts and Promoters of Students' Interests along with the interconnection of skills and motivates young children to do movement spontaneously and learn the spoken language simultaneously (Morales, 2008).

Researched studies among primary students receive positive impacts and give advantages that add to the growing database and suggest that musical listening activities do influence literacy development (Fisher, 2001). Continuously, it helps the understanding and it also stimulates and increases the students' interest to learn, enjoy and engage in the learning process along accelerating students' confidence, learning ability and skill when activities are highly motivating and memorable (Setia et al., 2012). Also, teaching new vocabulary through music has significantly increased achievement in English vocabulary learning, attitudes towards English course and retention of a new vocabulary of the students (Köksal et al., 2013) music significantly has a positive effect on children's pronunciation (Moradi, \& Shahrokhi, 2014). Continuously, background music improved vocabulary recall and retention better also creates a positive effect on young 
learners' motivation in language learning and their paying attention to the teacher.

Furthermore, advantages and benefits shown in studies among secondary and higher institution students such as the understanding of the language and culture that the students are learning through songs are much more attractive for them (Arevalo, 2010). Musical instruments were useful to explain to students some important concepts related to music such as the specific features about the appearance and sound of each one of these instruments (Pérez, 2010). The students instructed through pictures and music had the best performance in both vocabulary recognition and production (Zarei \& Salimi, 2012). Other advantages are musical intelligence significantly correlates with learning a foreign language and it may facilitate the learning of foreign languages (Shabani \& Torkeh, 2014). Evidence shows that music benefits rote memorization when various types of verbal information (e.g, multiplication tables, spelling lists) have been presented with music, memorization has been enhanced (Yousefi \& Farahmandian, 2014). Also, integrating soft music into an education classroom has beneficial qualities and the data collected indicates that students had positive behavior, during learning and memorizing words while they were listening to soft music (Moradi \& Zamanian, 2014).

\subsection{Scant Report of Challenges}

This area of research synthesis has revealed that the studies have mainly emphasized the benefits of using music in learning the second language without detailing its shortcomings. Regrettably, music is not emphasized in the Malaysian government preschools, as music teachers lack the appropriate knowledge and teaching skills. With that, there were several challenges faced by the researchers on the studies that are related to the use of music in the pedagogical strategies upon second language acquisition such as ways in which teachers infused music into their literacy instruction (Fisher, 2001). The methods cannot follow the traditional way in which the teacher is in front of her/his students, writing several structures on the blackboard but must be another strategic way also teaching a foreign language is not just about teaching structures; this is only one step of a big process which is why more interesting way need to be improved (Pérez, 2010).

The songs that are being used should be carefully selected to suit the students' abilities and the lyrics should be clear and the vocabulary in the songs should be appropriate to the students' proficiency levels (Setia et al., 2012). Continuously, the disadvantage and the challenges are that learning English as a foreign language is a demanding task for the majority of Iranian learners and sometimes, is boring and tedious to them which requires motivation and interest. For enhancing learning a foreign language, creating low anxiety and stress levels is a necessary condition that can be satisfied by inserting musical instructions (Shabani \& Torkeh, 2014). Another concern is that in order to improve students' segmental articulation (including the pronunciation of vowels, consonants, diphthongs, and triphthongs) and suprasegmental articulation (including stress pattern and intonation) many methods have been used for teaching pronunciation, but they were not conclusive and completely successful (Moradi \& Shahrokhi, 2014).

As for the educator's perceptions, they had difficulties in selecting songs and the recommendation is to provide them with interesting and enjoyable song materials for their classes ( Tse, 2015). The use of music in the classroom should be in a long-term intervention which would probably have a better impact because a short-term of six weeks produced a progressive result on pre-schoolers' reading skills (Augustine, 2015). Continuously, teaching EFL, especially for young learners, involves using creative and motivating methodologies and techniques. Students may have problems in learning vocabulary and pronunciation Furthermore, the students have poor pronunciation and lack of vocabulary competence as the Palestinian English Curriculum (English for Palestine) has a limited number of songs, games, and projects (Dajani \& Mclaughlin, 2009). Subsequently, challenges that are often faced by EFL educators are that they should exercise care in the song selection process. As there is a relation between song likeability, enjoyment of the learning environment, motivation for learning, and achievement, thus, EFL educators should select songs that students will like (Beasley \& Chuang, 2008).

\subsection{The Proven Affordances Support on the Effects of Using Music in Pedagogical Strategies among Second Language Learners}

The studies revealed approaches with different goals based on the audience in the analysis of using music to second language learners. Four groups have been targeted and participated in the studies: kindergarteners, primary students, secondary students, and higher institutions students.

\subsubsection{Effects on Integrating Music in Kindergarten Language Learning}

The studies were conducted in the context of projects that include kindergarteners as a participant of the studies. Results from the research synthesis revealed that there were many advantages from using music inside the education system among kindergarteners: motivate young children to do movement spontaneously, Contrastive music in pre-classical music learning, music and movement impacted upon the reading skills.

In a famous study (Rauscher, Shaw \& Ky, 1995), it was found that listening to music that is complex would help to elevate scores on a concurrent test of spatial reasoning. The works of Mozart were used and after listening, students' 
scores on a spatial reasoning test were eight points higher. The use of creative music pieces of contrast and song activities has made progressive for children in the kindergarten in improving their English ability (Lee, 2009). As Gardner (1992) wrote, "the single most important thing in education is for each person to find at least one thing that he/she connects to, gets excited by, feels motivated to spend more time with." For many children, music is that thing. Studies have also shown the connections music makes between thinking, learning, and emotions (Davies, 2000). Furthermore, integrating music into children's daily activities promotes literacy development, particularly with English language learners. Music is acknowledged to be the best tool to help improve in learning other languages. Other samples of using music among children in kindergarten have to be done by using music to study the awareness of reading among pre-schoolers (Augustine, 2015). Music can transform a classroom into a positive learning environment where children can succeed academically, socially, and emotionally. Besides, integrating music into children's daily activities promotes literacy development, particularly with English language learners (Ahmad et al., 2008).

\subsubsection{The Effects of Music among Primary Second Language Learners' Students}

Based on the 20 studies, there are 5 studies focuses on using music as a pedagogical strategy in learning the second language. There were many advantages arises from using music among primary students: stimulates the students' interest to learn, enjoy and engage in the learning process, accelerates students' confidence, increase learning ability and skill.

One of the ways to achieve the mastery of English is by using songs. A song is a form of language that uses tones and rhythm as it is also the media of universal language. According to Peacock (1997), many writers share the same opinion that learners are more motivated and stimulated in the foreign language classroom when authentic materials are used than artificial non-authentic materials. Coromina (2010), defends that a good song can prompt an interesting discussion in class. When students enjoy learning English through songs, they will indirectly make the effort to learn the lyrics of the songs they are listening to. A study was done by Köksal, Yağışan, \& Çekiç, (2013) resulted that new vocabulary through music has significantly increased achievement in English vocabulary learning, attitudes towards English course and retention of a new vocabulary of the students in the experimental group. Using music in learning language enables learners to open all memory channels and information encoded in different memory systems is remembered more easily as it can be retrieved from any possible memory system. This can also be understood from the fact that students who can store new vocabulary in different components of memory are the effects of the music.
Continuously, the use of media has been chosen to teach pronunciation to children. Music changes brain waves and makes the brain more active and receptive to leaning (Moradi \& Shahrokhi, 2014). The study using several instruments including the placement test, the pre-test, the post-test, voice recorder, and the book Song Time 3 resulted that it helps children to learn pronunciation like native speakers and students' pronunciation skill was improved after teaching and learning activity by using songs, the songs were good tools to teach pronunciation as a part of language.

Another study by Abdolmanafi \& Ataee (2014) in using Mozart Sonata (K.448, as used by Rauscher et al., 1993) as a background music and A DVD-player to broadcast the music along with the tape recorder to tape-record the participants' responses were conducted and the results were seen that the vocabulary recall and retention are much then before on the participants. Moreover, the background music had a positive effect on young learners' motivation in language learning and their paying attention to the teacher.

\subsubsection{The Effects of Music Used as a Learning Tool among Secondary School Students}

Five studies from the previous studies were identified to research secondary school students. By using music as a pedagogical strategy for the high school students, it has resulted in various positive results such as there is familiarity on the pronunciation of native speakers, increase performance in both vocabulary recognition and production, promotes memorization and various types of verbal information.

A study from Arevalo (2010), by experimenting listening performance of students throughout the development of six workshops based on the songs: Englishman in New York, Imagine, Mercedes Benz, Cats in the cradle, Zombie, and Where is the love? outcomes that the students can foster listening skills and engage in discussions about cultural and social issues. Likewise, results show that practicing listening with songs can become a good way to train students in the development of higher levels of comprehension. Furthermore, using songs from YouTube has shown advantages in teaching the second language to the secondary students. YouTube is famously known as an internet video search website (USA Today, 2006). Kelsey (2010) defines it as a website where you can upload and share videos. Participants were seen to be very enthusiastic in the lessons as they enjoyed listening to songs projected using the YouTube website and the reviews of using YouTube to improve the vocabulary competence among secondary school students is indeed an interesting and effective method (Setia et al., 2012).

Overall, this review has shown how the effects of music used among second language acquisition in secondary school students can enhance their learning skills. The use of music among the students aims to improve their learning abilities in second language acquisition. 


\subsubsection{Effects of Music among Higher Institutions Students}

Among 20 research studies, only four were identified done research on university students. The outcomes of using music resulted that it can develop listening comprehension, they can memorize significantly better and more while accompanying with soft music.

"Soft Music stabilizes mental, physical, and emotional rhythms to attain a state of deep concentration and focus in which large amounts of content information can be processed and learned (Brewer, 2005). Moradi \& Zamanian (2014) stated that by using soft music as a piece of background music has shown positive results such as music improves and influences the student's learning of English words. It also indicates that students had positive behavior, during learning and memorizing words while they were listening to soft music. Besides, it also creates a positive experience for students, promoted attention, positive attitude, and created a pleasant learning atmosphere. Continuously, by using English songs can be effective in the blended teaching-learning situations where teachers integrate both the traditional and modern ways of teaching listening through, for example, podcasts, blogs, etc. The integration of songs in the classroom settings can provide a variety to the might- be a boring atmosphere of the traditional classes, so, it can motivate the students and increase their interest in learning (Alipour, Gorjian, \& Zafari, 2012).

Overall, this review has shown how the effects of music used among second language acquisition in the higher institutions can enhance their learning skills. The use of music among higher institutions students aims to improve their learning abilities in the second language acquisition.

\section{Recommendations for Future Research}

This systematic review presents numbers of critical of critical recommendations for those who plan to investigate the advantages of using music in teaching second language learners.

\subsection{Conducted a Sample with a Bigger Size}

By using sample with a bigger participant, it could help to obtain more data, confirm the findings and enable the drawing of a more concrete conclusion regarding the effects of using songs to improve vocabulary competence. In addition, a longer experimental period is needed to enable the researcher to identify more valid conclusion and to see whether the improvements are consistent.

\subsection{Pursue a Research that Investigates the Effect of Using Songs in Developing Learners Writing Skills}

By doing a research using music to develop learner's writing skills, researchers could identify on how music affects a person's writing and its cognitive connection.

\subsection{The Ministry of Education, Curriculum Designers and Decision Makers Should Enrich English in the Country}

They should provide schools with modern and important materials that help in the use of songs in classes and they should motivate language educators to develop their competences especially in using songs.

\subsection{Conduct a Research Related to the Learner's Attitudes or Perceptions towards Using the Songs in Language Learning}

A study should not only be conducted on the subject without their perception towards what is being implemented on them. Thus, recommendation for the future research, a study on the student's perception itself ought to be done in order to identified further explanation on which way of using music that are more effective and suitable with them.

\subsection{Conduct a Research on Comparative Study between Male and Female Language Educators to Examine Specific Teaching Method to Improve Learner's Proficiency in the Language}

The research should not only be focusing on the student's; the way how music affects their learning but it has to be done on the educators itself too. The reason is that to identified weather there is a difference in the teaching method between the genders of the educators.

\section{Conclusions}

Based on this systematic review of 20 articles on the effects of music upon second language acquisition has shown interest in music among researchers and language educators but there is a lack of synthesis in the context of student's perceptions towards using music as a learning tool. The findings are described as well as the approaches and the strategies on implementing music in the pedagogical strategies. Initial, this review showed that the number of studies has shown fluctuations in studies research over the year, with contributions from researchers all over the world. This trend has shown consistency along with the review of the new findings on the effects of music upon second language acquisition. Next, the scant report of the theoretical and conceptual perspectives was reported in this review. Moreover, this survey of studies has revealed the perceptions, attitudes and usage patterns among language educators on second language learners are diverse. Continuously, the benefits and advantages of using 
music among second language acquisition have been drawn on the review. Subsequently, along with benefits, the challenges and issues were also jotted down in the review to balance the survey. Ultimately, the points from several pedagogical affordances support on the use of music in pedagogical strategies were illustrated. As time passes by, more language educators begin to understand the essentials in integrating music in the pedagogical strategies thus, raising awareness on how important it is in student's learning behavior. This study has presented findings and recommendations to help other researchers and language educators along with theoretical models to suggest new methods on how to integrate music into pedagogical strategies.

\section{REFERENCES}

[1] R Fisher, D. (2001). Early Language Learning with and without Music. Reading Horizons: A Journal of Literacy and Language Arts, 42 (1).

[2] Morales Neisa, C. (2008). Using rock music as a teaching-learning tool. Profile Issues in Teachers Professional Development, (9), 163-180.

[3] Beasley, R. E., \& Chuang, Y. (2008). Web-Based Music Study: The Effects of Listening Repetition, Song Likeability, and Song Understandability on EFL Learning Perceptions and Outcomes. TESL-EJ, 12(2), n2.

[4] Lee, L. Y. L. (2009). An Empirical Study on Teaching Urban Young Children Music and English by Contrastive Elements of Music and Songs. Online Submission, 6(3), 28-39

[5] Arevalo, E. A. R. (2010). The use of songs as a tool to work on listening and culture in EFL classes. Cuadernos de lingüística hispánica, (15), 121-138.

[6] Pérez Niño, D. F. (2010). The role of music in young learners' oral production in English. Profile Issues in Teachers Professional Development, 12(1), 141-157.

[7] Abidin, Z., Jafre, M., Pour-Mohammadi, M., Singh, B., Kaur, K., Azman, R., \& Souriyavongsa, T. (2011). The Effectiveness of Using Songs in YouTube to Improve Vocabulary Competence among Upper Secondary School Studies. Theory \& Practice in Language Studies, 1(11).

[8] Setia, R., Rahim, R. A., Nair, G. K. S., Husin, N., Sabapathy, E., Mohamad, R., ... \& Kassim, R. M. (2012). English songs as means of aiding students' proficiency development. Asian Social Science, 8(7), 270.

[9] Zarei, A. A., \& Salimi, A. (2012). The comparative effects of song, picture and the keyword method on L2 vocabulary recognition and production. Applied Research in English, $1(1), 43-56$.

[10] Köksal, O., Yağışan, N., \& Çekiç, A. (2013). The effects of music on achievement, attitude and retention in primary school English lessons. Procedia-Social and Behavioral Sciences, 93, 1897-1900
[11] Shabani, M. B., \& Torkeh, M. (2014). The relationship between musical intelligence and foreign language learning: The case of Iranian learners of English. International Journal of Applied Linguistics and English Literature, 3(3), 26-32.

[12] Moradi, F., \& Shahrokhi, M. (2014). The Effect of Listening to Music on Iranian Children's Segmental and Suprasegmental Pronunciation. English Language Teaching, 7(6), 128-142.

[13] Yousefi, A., Yekta, R. R., \& Farahmandian, H. (2014). The Effect of Modern Lyrical Music on Second Language Vocabulary Acquisition. Mediterranean Journal of Social Sciences, 5(23), 2583.

[14] Abdolmanafi-Rokni, S. J., \& Ataee, A. J. (2014). The effect of background music on vocabulary recall and retention of children learning English as a foreign language. International Journal of Basic Sciences \& Applied Research, 3(8), 491-495.

[15] Moradi, M., \& Zamanian, M. (2014). On effect of soft music on learning English language vocabulary. Theory and Practice in Language Studies, 4(2), 341

[16] Tse, A. Y. H. (2015). Malaysian teachers' perspectives on using songs in English language teaching. International Journal of Social Science and Humanity, 5(1), 87.

[17] Alipour, M., Gorjian, B., \& Zafari, I. (2012). The effects of songs on EFL learners' vocabulary recall and retention: The case of gender. Advances in digital multimedia, 1(3), 140-143.

[18] Augustine, C. (2015). How the use of music and movement impacts the learning of reading skills by preschoolers. Malaysian Journal of Music, 4(2), 74-90.

[19] Rezaei, M., \& Ahour, T. (2015). The Effect of Listening to English Songs on Iranian EFL Pre-intermediate Learners' Listening Comprehension. Journal of English Language Pedagogy and Practice, 8(16), 159-176.

[20] Iman, S. (2016). The effectiveness of using children's songs in developing elementary graders' English vocabulary and pronunciation in Jerusalem, Palestine. 